\title{
6
}

\section{Conceptual Approaches in Comparative Family Policy Research}

\author{
Hannah Zagel and Henning Lohmann
}

Comparative family policy research relies on concepts that define the relationships between the welfare state and the family. The literature contains several proposals on how to conceptualize these relationships for understanding country differences. Depending on the research tradition, the conceptual approaches vary in their interpretation of what is the main challenge in these relationships. For example, whether the focus is on economic autonomy, care relationships, class differences, or on any combination of these.

Closely linked to the theoretical perspective on the family-welfare nexus is the methodological practice dominant in the respective research traditions, although the links are not deterministic. Researchers have developed their concepts within the epistemological logics of their respective research domains. Comparative historical research stresses the need for in-depth analysis of spatio-temporal configurations while quantitative comparative welfare state research attempts to achieve a high degree of measurability of general concepts across contexts. In comparative family policy analysis, there is arguably a good level of exchange of conceptual ideas between the different comparative approaches.

\section{H. Zagel (凶)}

Humboldt-University zu Berlin, Berlin, Germany

e-mail: hannah.zagel@hu-berlin.de

H. Lohmann

University of Hamburg, Hamburg, Germany

e-mail: henning.lohmann@wiso.uni-hamburg.de 
This chapter provides a systematic overview of some of the most popular and widely used concepts in comparative family policy research. We situate each conceptual approach in their respective research tradition, define the concepts' main characteristics and demarcate them from similar ones. Our discussion is guided along six criteria, which highlight differences and similarities between concepts. These are criteria with regard to the scope of the concepts as well as to methodological issues. Questions related to the conceptual scope are: (1) Who is considered as the main addressees of family policy interventions? (2) Does a concept focus on gender and/or intergenerational relationships? (3) Is the concept defined from the perspective of the caregiver and/or the care receiver? (4) Does the concept consider the state and/or the market as welfare providers alongside the family? The main methodological distinction is whether a concept points to ideal types in family policy regimes or not (5). Last, concepts can be differentiated into unidimensional and multidimensional ones (6). All conceptual approaches we discuss are rooted in comparative welfare state research, which considers nation-states as the main unit of analysis. To foreclose some of our conclusions, the similarities between the concepts seem often stronger than the differences. However, we show that there are important nuances, which can be critical in drawing comparative conclusions about family policy and its expected outcomes. The nuances have been blurred over time, and it is rare to find explicit arguments for using one rather than another concept in empirical comparative family policy research. With the discussions in this chapter we provide the basis for such reflections.

The remainder of this chapter is organized in three parts. In the next section we discuss research traditions, dominant ideas, and methodologies in the field. What follows is the heart of the chapter, presenting definitions and discussions around two classes of concepts in comparative family policy research: categorical concepts (captured in typologies) and gradual concepts (measurable as indexes or scales). In the concluding section we propose criteria by which to classify and evaluate concepts as indicated above. These criteria can be used to inform decisions about which concepts to use in research.

\section{Research Traditions, Ideas, and Methodologies}

Conceptual approaches in comparative family policy research are rooted in distinct research traditions. Arguably, today, the ideas once driving different conceptualizations are less visible in research applying them, and are often 
deemed less important. Understanding the theoretical origins of conceptual ideas however supports an informed use of concepts in empirical research. Further, research traditions are linked to particular methodological strategies. Understanding these links helps to contextualize conceptual approaches and to position one's own research in the field. It should be noted that research traditions are far from being homogenous, nor are the methodological practices anchored within them. There are however broad differences that can be identified for orientation in the field.

\section{Research Traditions}

There are at least three main research traditions in which concepts used in comparative family policy research emerged: family well-being, feminist and mainstream comparative welfare state research. The perspective on family policy differs across research traditions and who is regarded as the main addressee of policy interventions. The first tradition, which we here call the "family well-being research tradition," has a focus on the family as a social institution. It is often motivated by the recognition of "the importance of the family in society" (Kamerman \& Kahn, 1978, p. 1). The family, usually defined by the presence of children and excluding kin relationships beyond the nuclear family, is understood to fulfill different social functions. ${ }^{1}$ For example, it is the site of social reproduction, socialization, and child development, but also of parental challenges to maintain the family socially and economically. Family policy, then, is seen as state intervention "to and for the family" (Kamerman \& Kahn, 1978, p. 3), allowing the family to realize their respective functions. Research in this tradition acknowledges the variation in the forms of intervention as well as in the goals of family policy. Kaufmann (2002) differentiates eight different motives used to legitimate family policy intervention: the institutional motive, the natalist motive, the eugenic motive, the economic motive, the societal motive, the sociopolitical motive, the women's issues motive and the children's welfare motive. The institutional motive legitimizes family policies by the need to preserve the family as a social institution with its own value. The natalist motive on the other hand centers on the question of demographic reproduction, while the eugenic motive pursues control over the genetic reproduction of the population. The economic motive follows the idea that family policy should guarantee the family's economic function in production and consumption,

\footnotetext{
${ }^{1}$ Although apparently influenced by sociological functionalism, which defined the (nuclear) family by its social functions, this discussed strand of the family policy literature does not operate with the same degree of normative reasoning.
} 
and the societal motive is similar but considers reproductive functions as well. The sociopolitical motive then legitimizes family policies by the need to balance inequalities between parents and people without children, while the women's issues motive primarily aims to address mothers' disadvantages. Last, the children's welfare motive sees child well-being at the center of family policy intervention. Kaufmann argues that some of these motives overlap, and that some are used jointly, but that it would be short-sighted to assume one of the motives would cover the whole range of family policy issues (Kaufmann, 2002, p. 432). This reveals one of the key differences to the feminist tradition in comparative family policy research, the second one we consider here-although viewing feminism as a homogenous approach limited to "women's issues" is certainly too narrow a view.

The feminist tradition in comparative family policy research tapers in what has been called gendered welfare state research. This literature combines two research fields: feminist analysis of women's rights and comparative research of social policy and welfare states (Sainsbury, 1996). Gendered welfare state research has traditionally taken a critical stand. A common denominator of this literature was the underlying feminist ideas that patriarchal structures in society should be exposed and dismantled. A key concern was the omission of women's positions in mainstream welfare state research, and new concepts and theories were proposed to address this gap (e.g. Lewis, 1992; Lister 1994; O'Connor, 1993; Orloff, 1993; Pascall, 1996). Among the central goals was to unpack the various relationships between women and the welfare state. Theories addressed the male bias in theoretical explanations of social phenomena such as social policy provision and receipt. New concepts, then, enabled analyzing women as the targets and beneficiaries of welfare states.

However, rather than arguing that gender-centered measures of policies reflect what is good or bad for women, as often implied in critiques of this approach, this research highlights that the relationship between gender and the welfare state is complex (Lewis, 1997). A key theoretical contribution of the feminist perspective has been to understand the welfare state's role in affecting both paid as well as unpaid work. Including gender as an analytical category provided the conceptual tool for highlighting that work in the family was overwhelmingly done by women. Two concepts that enable a gendered analysis of welfare states are O'Connor's (1993) personal autonomy concept and Orloff's (1993) capacity to maintain an autonomous household or self-determination concept. While these can be applied to analyze the relationships between the welfare state and both men and women (Daly, 1994), they focus mainly on paid work (Lewis, 1997). In sum, many important concepts used in comparative family policy research evolved in the feminist 
research tradition, because it made reliance on the family to provide welfare visible as a distinguishing feature of welfare states.

Comparative welfare state research has traditionally lacked this focus on the family, looking instead at the relationship between capital and labor in welfare states with decommodification as a central concept. Decommodification provides wage earners with an alternative option to maintain a livelihood and is a power resource in wage bargaining processes. As a response to feminist criticism of the focus on paid work, representatives of this research tradition have later added concepts to account for work done in families to their initial frameworks (Esping-Andersen, 1999; Korpi, 2000). The initial classifications of welfare regimes that emerged in the power resources research tradition (conservative, liberal, and social democratic welfare regimes) were maintained even after adding the family as a welfare provider to the theories.

\section{Methodological Practices}

Comparative family policy research is a methodologically heterogeneous field (see Lohmann \& Zagel, 2018 for a discussion on methodological approaches). Each of the above-discussed research traditions features a specific core methodological practice. In all traditions, comparative historical research of institutional development was important. This work is overall less concerned with defining quantifiable dimensions. In particular the feminist research tradition has taken a stance for comparative historical analyses. One argument in favor of this approach is that institutional settings are characterized by historical processes and complementarities which cannot be captured in single quantitative indicators. ${ }^{2}$ The definition of welfare state models or welfare state types is based on an analysis of these historical processes. In the comparative welfare state research tradition both quantitative and comparative historical institutional analyses were used. In the past, quantitative comparative research has often relied on analysis of social expenditure data (Skocpol \& Amenta, 1986), not least due to a lack of comparable institutional data. As a response, the establishment of the Social Citizenship Indicator Program (SCIP) at the Swedish Institute for Social Research at Stockholm University by Walter Korpi in the early 1980s was path-setting. From then on, other databases have emerged, including those on family policy indicators, although data availability remains an issue in the

\footnotetext{
${ }^{2}$ For example, Lewis argues that some quantitative studies fail to be convincing because their operationalization of central welfare state dimensions is too crude, such as operationalizing pronatalism with demographic variables (Lewis, 1997, p. 168).
} 
field of comparative family policy research (Lohmann \& Zagel, 2018; see also Chapter 24 by Sirén, Doctrinal, Van Lancker, \& Nieuwenhuis in this volume). Quite often also quantitative research in the field aims at the identification of models or types. But here, country cases are assigned to types based on quantitative indicators or composite indexes. A well-known example is the use of a decommodification index to assign countries to welfare regime types (Esping-Andersen, 1990). In family policy research, typologies of familialism and de-familialism are examples for this approach (Leitner, 2003; Saraceno $\&$ Keck, 2010). Concepts such as familialism are, in principal, independent of methodological approaches. That means, most of the concepts discussed below cut through methodological divides and may be used in both caseoriented or variable-oriented approaches. However, it will become obvious that some are more usefully applied in one than in another research design.

\section{Concepts of Comparative Family Policy Analysis}

Our discussion of concepts in comparative family policy research is structured around the distinction between two classes of concepts: categorical and gradual concepts. Categorical concepts characterize qualitative differences between countries, while gradual concepts are used to indicate (quantitative) degrees of institutional characteristics and policy intervention on an implicit or explicit scale. ${ }^{3}$ The former consider countries as cases, the latter as units of analysis for which values of variables are observed. First, we discuss typologies, such as the male breadwinner model and family support models, as a specific case of categorical concepts. Second, we give an overview of the conceptual discussion of gradual concepts such as defamilization, familization, and related ones. Figure 6.1 gives an overview of the concepts we selected for discussion in this chapter, illustrative for the differences between the approaches. It also shows the interlinkages between concepts. In particular, overlaps between categorical concepts (typologies) and gradual concepts will become clear throughout, as the latter is often used for generating the former.

\footnotetext{
${ }^{3}$ This distinction should not be confused with contrasting quantitative and qualitative methodologies.
} 


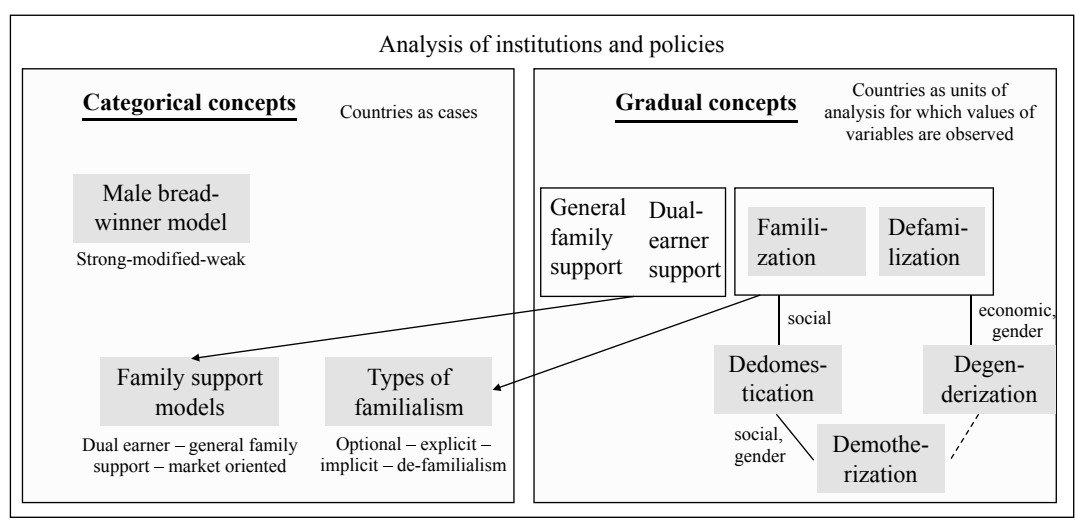

Fig. 6.1 Examples of categorical and gradual concepts in comparative family policy research (Note See text for further details and references)

\section{Typologies as Conceptual Devices}

Typologies are popular and used extensively for defining theoretical ideal types in comparative welfare state research. Mainstream welfare state typologies have widely been criticized for their ignorance of gender inequality. New theoretical concepts were needed that considered policy effects on the gender division of labor. According to Sainbury (1994), two approaches were used to respond to the critique of gender-blindness: the first one argued for integrating gender and family alongside class concepts into the mainstream theories; and the second one suggested to dismiss the country groupings in mainstream research while producing typologies purely based on gender and family (see Hook, 2015 for a similar argument). The two responses developed successively.

As an immediate critique of Esping-Andersen's typology, Lewis (1992) introduced the concept of the male breadwinner model for typologizing welfare regimes. Second, based on this work, Esping-Andersen (1999) and Korpi (2000) included family and gender into their comparative frameworks. While the former added the defamilization concept to refine his Three Worlds typology, Korpi (2000) defined different types of family support models to form distinct regime types in combination with class inequalities. We will now discuss the male breadwinner concept and the family support models in turn. Defamilization and related concepts will be discussed in the following subsection. 


\section{Male Breadwinner Model}

Ever since the concept emerged in the 1990s, the male breadwinner model is a key reference point in comparative family policy research. As a precursor in this field, Langan and Ostner's (1991) study draws on the very ideas underpinning the concept, but was still lacking a systematic conceptual framework. Langan and Ostner assess Esping-Andersen's typology by asking how policies affect the gender division of labor, focusing on the degree of women's economic dependency on a male earner across countries. Lewis (1992) then introduces the concept of the male breadwinner model as an analytical framework for cross-country comparison. The concept builds on the 1980s discussion around women's rights and the family wage (Land, 1980). Analyzing four countries' adherence to the model, Lewis (1992) finds that Britain and Ireland are historically strong breadwinner countries, France a modified and Sweden a weak breadwinner state. This initial formulation of a breadwinner model typology counts as one of the key feminist responses to Esping-Andersen's welfare regime typology. Country groupings were later added and adapted (e.g., Lewis \& Ostner, 1994).

The male breadwinner model is broadly defined as the "idea and norm of a 'male breadwinner' and a 'secondary' female wage earner (...) built into the welfare system" (Lewis \& Ostner, 1994). The breadwinner model typology rests on the conviction that any classification of regime types must incorporate the relationships between paid and unpaid work and welfare. The argument is that a sole focus on paid work omits the gendered nature of welfare provision. The concept of the breadwinner model as used by Lewis (1992) reflects welfare states' different degrees of support to the gendered division of labor, by granting social rights to women primarily as wives or as individuals. It sometimes appears difficult to pin down exactly what the breadwinner model is. Although it is clear that the core of the concept is about differences in policies, it sometimes seems to describe the state of gender relations in society more broadly. In this aspect it overlaps with Pfau-Effinger's (1996, 2005) gender arrangement concept, which is however critical of "institutionalist" perspectives, and more explicitly based on cultural differences between countries.

The breadwinner model concept is used to describe country differences and change over time within countries in the relationship between paid and unpaid work and the welfare state. Since the initial formulation of the concept, the erosion of the male breadwinner model in European policies has been noted (Lewis, 2001; Lewis \& Giullari, 2005). In ensuing discussions, the model has been juxtaposed to what is called an adult worker model. 
Policies reflecting the adult worker model address adults as employable individuals rather than men and women as spouses with specific roles and responsibilities within the family. Governments promote an adult worker model in the hope of it fostering economic growth, tackling poverty, increasing gender equality in the labor market, and addressing the problem of deteriorating dependency ratios (Lewis, 2006, p. 9). Hence, adult worker model policies assume that men and women should claim social entitlements on the basis of "sameness" rather than on the basis of "difference" as is the case in a strong male breadwinner state (Lewis \& Ostner, 1994).

One of the main questions raised by the observers of potential shifts from male breadwinner to adult worker model is whether policies that are designed to support an adult worker model are also gender-sensitive (Lewis, 2009). That means, for example, whether work-family reconciliation policies with the aim of bringing women into employment consider gender equality. Or whether such policies go at the expense of women who are now expected to take on the same level of paid work without being relieved from unpaid work. Lewis and others find that "gender equality" has been used mostly rhetorical and instrumental rather than as a genuine policy goal (Daly, 2011; Lewis, 2009; Lewis \& Giullari, 2005). This discussion again points to the difficulty of using the breadwinner model concept for comparing institutional settings across countries, because often it has more in common with an ideational concept.

This fuzziness notwithstanding, research continuously refers to the male breadwinner model concept. ${ }^{4}$ It has proved to be of some relevance in the comparative family policy literature. Most empirical studies explicitly analyzing the breadwinner model typology take a historical perspective focusing on a small number of country cases (Lewis, 1997). There are however several large- $\mathrm{N}$ studies that group countries based on indicators of women's paid work. Few studies actually look at household level work-family arrangements (Hook, 2015), as would be adequate for a breadwinner model perspective. One exception is Lewis, Campbell, and Huerta (2008), who descriptively examine empirical patterns of paid and unpaid work in couples across Europe, but without attempting to identify clusters.

\footnotetext{
${ }^{4}$ Lewis (1992): 162 citations in 2018 according to google scholar as of March 2019.
} 


\section{Family Support Models}

The second prominent conceptual perspective in research using typologies for comparing family policies across countries explains welfare state differences with variations in family support models (Korpi, 2000). This strand originated in the comparative welfare state research tradition. It is characterized by an attempt to incorporate gender as an analytical category into existing comparative welfare state frameworks. Korpi's (2000) approach is strongly influenced by the feminist critique of Esping-Andersen's 1990s study. One of his main contributions is, however, to consider gender inequality by simultaneously accounting for class inequality in the classification of welfare regimes. Korpi argues that "effects of welfare states on patterns of inequality in terms of gender and class can be asymmetrical" (2000, p. 142). That means, for example, welfare states with generous redistribution between high- and lowincome groups are not necessarily those that are most effective in reducing gender inequality.

The family support model concept distinguishes three distinct family support models: the general family support model, the market-oriented support model, and the dual-earner support model. Korpi applies a social rights perspective situated in the state-market-family triangle (Korpi, 2000, p. 144). The general family support model fosters the traditional gender division of labor while dual-earner support enables women's employment and the socialization of care work. Welfare states that provide neither support to the nuclear family, nor to the dual-earner family are assumed to have opted for family support to be provided by the market. Korpi argues that these theoretical ideal types reflect both policies and policy goals regarding gender equality (ibid.).

Two characteristics are central in Korpi's (2000) approach, the focus on institutions and its multidimensionality. The focus on institutions is justified by the alleged need for welfare state typologies to focus on institutional indicators rather than outcomes (Korpi, 2000). From this point of view, in particular some approaches in the feminist tradition are guilty of conflating institutional and outcome perspectives. For example, the male breadwinner model reflects both, policies (institutions) and women's employment (outcome). Further, Korpi and his colleagues stress that their approach is multidimensional (Korpi, 2000; Korpi, Ferrarini, \& Englund, 2013). In his early study, Korpi explains that family policy has to be conceptualized and measured focusing on more than one dimension, because policymakers face the fundamental dilemma of whether to grant women the same or different kinds of rights than men (Korpi, 2000, p. 140). Hence, if one 
policy dimension considers support to women's employment, another one has to account for support to unpaid family care. Family policy multidimensionality is consequently conceptualized as the position of a country in the space between the two dimensions of general family support and dual-earner support (Korpi, 2000; Korpi et al., 2013). With this, Korpi's typology results from crossing two gradual concepts (see Fig. 6.1).

Ferrarini (2006) adopts the framework proposed by Korpi precisely for the advantages of a multidimensional perspective. He adds the "Contradictory family policy model" to the ideal types of family policy models where both general family support and dual-earner support are generous (Ferrarini, 2006). The notion of contradiction (also termed pluralistic, ibid., p. 13) reflects the assumed underlying policy ideology. Hence, while Ferrarini (2006) builds his typology on the same gradual concepts as Korpi, he deduces an additional type from the combination of specific values on these dimensions.

\section{Gradual Concepts}

In contrast to using such concepts as stepping stones for creating typologies, gradual concepts are also often used without higher order aims (typologies). In this section we consider defamilization and its offshoots as a representative of a second class of concepts in comparative family policy research. Defamilization shares theoretical roots with other concepts such as the male breadwinner model. As the latter, the concept of defamilialization (Lister, 1994) or de-familization (McLaughlin \& Glendinning, 1994) emerged from the feminist critique of Esping-Andersen's welfare state analysis and its central concept of decommodification. In this section, we map the discussion around the concept of defamilization, and we review other concepts that evolved from it. Underpinning the concept of defamilization is (again) the idea that the family is a welfare provider, but that the family is also characterized by strong social and economic dependencies among its members. By providing certain policies, welfare states can alter the degree of family dependence and with it the relative importance of state, market, and family as welfare providers. These links are at the heart of the defamilization concept.

The interpretation of the defamilization concept varies, but the different possible readings go rather unnoticed in the literature. The relative lack of systematic discussion of the concept's theoretical roots and conceptual facets is striking given its popularity in comparative research (but see e.g. Kurowska, 2018; Leitner \& Lessenich, 2007; Lohmann \& Zagel, 2016, Zagel \& Lohmann, (forthcoming). The concept seems to polarize into those 
who use it unquestioned and those who are skeptical about its use. The latter position manifests in studies that take defamilization as a starting point for defining alternative or additional concepts. These concepts are generally less comprehensive, or focus on a certain aspect of defamilization, like for example the concepts of dedomestication (Kröger, 2011), degenderization (Saxonberg, 2013), and demotherization (Mathieu, 2016). Often, the motivation for defining these offshoot concepts seems to result from differences in uses and understandings of the defamilization term. The systematic discussion of such differences, to which we contribute in the following, is likely to resolve some of the issues.

\section{Defamilization}

There are at least three influential definitions of defamilization. The first was proposed by Lister who defines defamilialization as "the degree to which individual adults can uphold a socially acceptable standard of living, independently of family relationships, either through paid work or through the social security system" (1994, p. 37). McLaughlin and Glendinning coined the second definition: "[D]e-familization is constituted by those provisions and practices which vary the extent to which wellbeing is dependent on 'our' relation to the (patriarchal) family" (1994, p. 65). In contrast to Lister, the definition by McLaughlin and Glendinning does not put such a clear emphasis on economic independence. A third definition was proposed by Esping-Andersen who adopted the concept as a reaction to the critique of his earlier focus on decommodification for welfare regime comparison: "I shall use 'de-familialization' [...] to capture policies that lessen individuals' reliance on the family; that maximize individuals' command of economic resources independently of familial or conjugal reciprocities" (1999, p. 45). While Lister and McLaughlin and Glendinning originally introduced the concept to comparative social policy research, Esping-Andersen transferred it into what has been referred to as mainstream welfare state literature. Later uses of the concept are often strongly influenced by Esping-Andersen's reading of the earlier proposals. Clearly, Esping-Andersen's definition stresses the aspect of economic independence while, in particular, McLaughlin and Glendindinning's definition includes policy effects on other family dependencies as well. Drawing on this wider definition Leitner and Lessenich (2007) argue that defamilization is a multidimensional concept. That is, state and market would not only affect economic, but also social dependencies, which they understand as relationships between caregivers and receivers of care. This multidimensional definition is not widely used in the literature, nor 
is there a consensus on differentiating the social and economic dimensions of defamilization. The analytical distinction makes sense because social and economic outcomes of policies are often intertwined.

There are two indications of the lack of conceptual clarity of defamilization. First, the incoherent spelling of the term in the literature, and second, the lack of precision in quoting the original sources of the concept. As regards the spelling, neither the occasional deviation from the original spellings, nor the intentional use of a specific spelling that an author makes explicit would be so surprising. It is the uncommented use of particular ways of spelling that suggests arbitrariness. For illustration, we found four different ways of spelling: defamilialization (Lister, 1994; Mathieu, 2016; Saxonberg, 2013), de-familialization (Esping-Andersen, 1999; Leitner, 2003; Saraceno \& Keck, 2010), de-familization (McLaughlin \& Glendinning, 1994; Saraceno, 1997), and defamilization (Cho, 2014; Kröger, 2011; Lohmann \& Zagel, 2016). We risk over-interpreting the differences if we were to assume different intended meanings by these choices of spelling, especially regarding the use of a hyphen. And yet, we would argue that a systematic discussion of these differences in terms of substantive meanings could contribute to a more coherent use of the concept. Second, the imprecise reference to the original sources does not help to reach an agreement on the concept. For instance, Esping-Andersen (1999) does not refer to either of the two original proposals by Lister (1994) and McLaughlin and Glendinning (1994). Other authors seem to mix up sources and quotations of the early publications on the concept (comparing, for example, Mathieu, 2016, p. 578; Saxonberg, 2013 , p. 28f). As a consequence, in these discussions, differences in the initial definitions by Lister (1994) and McLaughlin and Glendinning (1994) were blurred. Furthermore, new aspects and interpretations have been added to the concept.

Most importantly, a number of scholars have pointed out that familization and defamilization should not be framed as negatives or as opposite poles on a continuous scale (Eggers, Grages, Pfau-Effinger, \& Och, 2020; Leitner, 2003; Lohmann, 2009; Lohmann \& Zagel, 2016), but may be regarded as two related but distinct concepts. The fact that a number of welfare states combine familizing and defamilizing policies shows that the two are not mutually exclusive (e.g., in the form of optional individualism or optional familialism; Leitner, 2003; Lohmann \& Zagel, 2016). Related to this, the concepts of familization and defamilization have been used jointly for defining types of familialism, de-familialism, or individualism (e.g., Leitner, 2003, see Fig. 6.1). Defamilization then came to capture (quantitative) degrees to which certain policies provide relief from family 
dependencies, while types of de-/familialism characterize qualitative differences between combinations of such policies. Gender and intergenerational (i.e., children-parents-grandparents) dependencies are at the heart of the debate around defamilization. And although other characteristics such as sibling order, matri- or patrilineal lineage are usually sidelined, the concept of defamilization is principally open to them.

A crucial but unresolved question in the discussion of defamilization is whether only the state or also the market is considered as sources for independence from the family. Economic independence from the family is often construed as commodification, i.e., reliance on the market for acquiring own income as an alternative to depending on family members' economic support. In contrast, social independence is more often discussed as being achieved via state provision of services. That means, statutory provision of care services such as childcare is defamilizing because it relaxes social dependence between caregiving and care receiving family members. However, the distinction between state or market as alternative providers to the family is not as clearcut. For instance, Lister (1994, p. 37) explicitly mentions "the social security system" as alternative to "paid work" as source of economic independence. A second example is Leitner, who focuses not only on economic but also social independence, discusses — with reference to Esping-Andersen (1999)—also "de-familialization through market driven service provision" (2003, p. 356f). For example, childcare services are often provided by for-profit organizations.

Against the background of this wide, multidimensional understanding of defamilization we now discuss more recently proposed concepts such as dedomestication (Kröger, 2011), degenderization (Saxonberg, 2013), and demotherization (Mathieu, 2016). While the first and the third are construed as additional concepts to defamilization, the second is proposed as an alternative one.

\section{Dedomestication}

Kröger's (2011) proposal of an additional concept labelled "dedomestication" is based on a thorough discussion of the literature on defamilization. He recognizes in detail the differences in the concepts as proposed by Lister (1994) and McLaughlin and Glendinning (1994). Consequently, he borrows from Leitner and Lessenich (2007) the distinction between economic and social independence as well as their critique of a narrow, economic understanding of defamilization in the mainstream welfare state literature. Although Kröger adopts a wide notion of defamilization that 
includes both economic and social aspects, and argues strongly for the integration of the perspectives of caregivers and receivers of care, he rejects the use of the term defamilization. Instead, he argues that defamilization tends to be used more narrowly in the literature, and that using it in a different, more encompassing way would cause "conceptual confusion" (Kröger, 2011, p. 429). Therefore, - despite his own understanding of the concept-he opts for the use of "defamilization" to describe the degree of economic independence and proposes "dedomestication" to describe the degree of social independence only (see Fig. 6.1).

Dedomestication "is understood as the degree to which social care policies make it possible for people to participate in society and social life outside their homes and families. Dedomestication thus refers to freedom from a confinement to the domestic sphere or, using the term of Lewis (1997), to citizens' right to limit their engagement in unpaid informal caring. From the care receiver's perspective, dedomestication is about not being dependent on informal care from close persons, in other words, about citizens' right to receive formal care (Knijn \& Kremer, 1997)" (Kröger, 2011, p. 429). With its explicit reference to the right of participation within the public sphere and of limiting unpaid informal caring, Kröger (2011) addresses the gendered consequences of caring arrangements. Still, dedomestication is not predominantly about gender. By stressing the rights of receivers of care the concept also explicitly addresses intergenerational dependencies. Although analytically convincing, the concept has not been picked up widely. Its measurement has seemingly never evolved from the rather tentative sketch in the original article based on data on childcare for zero- to two-year olds-leaving out indicators for the care provisions for older children, disabled and older people due to a lack of data. Kröger himself critically comments on the value of the proposed index: "The end result of this empirical experiment is another ranking order of welfare states, based on the level of dedomestication of their formal childcare provisions for children under three years. It can be questioned if such league tables have any theoretical or policy significance" (2011, p. 436).

\section{Degenderization}

In contrast to Kröger, Saxonberg (2013) applies a narrow interpretation of defamilization in his proposal of replacing the concept with that of degenderization. A selective reading of Lister $(1994,2003)$ and Esping-Andersen (1999) results in a purely economic understanding of defamilization. Saxonberg overlooks the social dimensions of defamilization despite referring to Leitner (2003) whose main focus is on the caring function of families. $\mathrm{He}$ 
interprets defamilization as a concept addressing primarily gender relations, and even more, as a normative concept directed at creating gender equality. Overall, Saxonberg arguably takes an unnecessary normative stance in what claims to be an analytical discussion. Arguing from this position, he states that researchers "are not even able to reach an agreement as to whether familialization is bad and defamilialization is something good!" (Saxonberg, 2013, p. 29). This bold statement disregards the careful discussions about the complex relationships between gender and the welfare state in this research area (Daly, 1994; Lewis, 1997). An illustrative example is the concept of "optional familialism" (Leitner, 2003), which is based on the understanding that preferences for caring do not need to be in conflict with policies lowering the burden of care. In other words: contrary to Saxonberg's claims, single policies are not to be judged unidirectionally but in terms of the options they offer. Narrowing down previous proposals to gendered economic dependence (see Fig. 6.1) leads Saxonberg to a general critique of the concept of defamilization as "simply too ambiguous" and that it "does not really clearly describe the main goals of mainstream feminist scholars writing on gender" (2013, p. 27). Instead, he proposes "degenderization" as a more adequate concept.

In our reading, the concept of degenderization fails to be convincing, because it is a narrowed down, normative version of defamilization. Kurowska comes to a similar, slightly more favorable conclusion. She "supports most of Saxonberg's critical arguments towards (de)familialization when it is understood (and applied) as a comparative and evaluative perspective focused on gendered aspects of welfare states." (2018, p. 30). However, Kurowska also stresses that (de)familialization may be interpreted more comprehensively, and as such is able to provide useful insights into the role of the welfare state that go beyond gender issues, particularly for securing the welfare of children and the elderly. She therefore argues in favor of the mutual irreplaceability of the two concepts.

\section{Demotherization}

A third new concept-demotherization—was recently proposed by Mathieu (2016). It is defined as follows: "The concept of demotherization refers to the degree of independence mothers enjoy from the necessity of performing care work, and most specifically childcare" (Mathieu, 2016, p. 577). Although Mathieu shares the focus on gender equality with Saxonberg (2013), she acknowledges the multidimensionality of defamilization. And although the 
title "From the defamilization to the 'demotherization' of care work" seemingly refers to demotherization as an alternative, Mathieu is clear in proposing it as an additional concept. Mathieu-like Kröger (2011) with his proposal of dedomestication-adds a concept which is focused on care relations and, thus, on the social dimension of defamilization (see Fig. 6.1). ${ }^{5}$ In contrast to Kröger, Mathieu explicitly genders dedomestication as it "does not account for the fact that care work can be performed within the family, by other relatives than by the mother" (Mathieu, 2016, p. 588).

\section{Conclusion and Outlook}

Comparative family policy research relies on concepts by which differences in countries' reliance on the family as a welfare provider can systematically be evaluated. The relationship between the welfare state and the family is a key aspect in any conceptual approach to comparative family policy research. Concepts however vary in their focus on different aspects of this relationship.

Our discussion was guided by six criteria we laid out in the introduction. (1) Who is considered the main addressee of family policy interventions in the concept? The main distinction is whether families or individuals living as families are considered as main addressees. Where individuals are addressed, these can be children, women, men, mothers, fathers, parents, and grandparents. Most prominently, concepts arising from feminist welfare state critique have brought forward a perspective of individual's - men and women'ssocial rights, a perspective which all recent concepts share to a stronger or lesser degree. Children as family members with individual rights are less explicitly discussed but have obtained more attention recently (Daly, 2020; Palme \& Heimer, 2019). (2) Does the concept focus on gender and/or intergenerational relationships? This question relates to the first but focuses on social relationships and the dependencies arising of those. While some concepts focus explicitly on the relationships between women and men, others integrate intergenerational relationships too, such as defamilization in a broad reading or family support models. (3) Is the concept defined from the perspective of the caregiver and/or the care receiver? Concepts, such as Leitner's types of familialism or Kröger's concept of dedomestication, are rooted in the analysis of care relationships. These concepts are more sensitive to include the perspective of caregivers and receivers of care. (4) Does the

\footnotetext{
${ }^{5}$ Mathieu uses gradual concepts—-de-/motherization and de-/familization- to define different types of maternalism, an approach similar to Leitner (2003). For the sake of readability, this is not depicted in Fig. 6.1.
} 
concept consider the state and/or the market as welfare providers alongside the family? All concepts share the view of family, state, and market as welfare providers. The question whether the state or the market are sources for independence from the family is not addressed explicitly in all concepts. (5) Does a concept point to ideal types in family policy regimes? We distinguished between gradual concepts and categorical concepts. The latter categorize countries into types which may also be interpreted as ideal types (although the distinction between ideal and real types is often blurred). Some categorical concepts use the combination of gradual concepts as basis for a typology. (6) Are there are any subdimensions to the concept? Categorical concepts are by definition multidimensional as they consider countries as cases, i.e., as units defined by a combination of, often complementary, characteristics. Thus, the question of multidimensionality arises only in the discussion of gradual concepts. We argued that defamilization is understood as unidimensional as well as multidimensional concept, which is a root for misunderstandings in the reception of the concepts since it was proposed.

In this chapter, we have shown that the different concepts developed in distinctive research traditions, which featured specific methodological practices. We further discussed the specifics of some of the most prominent concepts and how they developed over time. One of the conclusions that we draw from this evaluation of the literature is that there are many similarities in the underlying ideas behind the concepts. However, there are also important differences, which so far have partly gone unnoticed mostly because of a lack in systematic discussion.

\section{References}

Cho, E. Y.-N. (2014). Defamilization typology re-examined: Re-measuring the economic independence of women in welfare states. Journal of European Social Policy, 24, 442-454.

Daly, M. (1994). Welfare states: A gender friendly approach. In D. Sainsbury (Ed.), Gendering Welfare States (pp. 101-117). New York, NY: Sage.

Daly, M. (2011). What adult worker model? A critical look at recent social policy reform in Europe from a gender and family perspective. Social Politics: International Studies in Gender, State \& Society, 18, 1-23.

Daly, M. (2020). Children and their rights and entitlements in EU welfare states. Journal of Social Policy, 49(2), 1-18.

Eggers, T., Grages, C., Pfau-Effinger, B., \& Och, R. (2020). Re-conceptualising the relationship between de-familialisation and familialisation and the implications for gender equality-The case of long-term care policies for older people. Ageing \& Society, 40(4), 869-895. 
Esping-Andersen, G. (1990). The three worlds of welfare capitalism. Princeton: Princeton University Press.

Esping-Andersen, G. (1999). Social foundations of postindustrial economies. Oxford: Oxford University Press.

Ferrarini, T. (2006). Families, states and labour markets: Institutions, causes and consequences of family policy in post-war welfare states. Cheltenham, UK: Edward Elgar.

Hook, J. L. (2015). Incorporating 'class' into work-family arrangements: Insights from and for three worlds. Journal of European Social Policy, 25, 14-31.

Kamerman, S. B., \& Kahn, A. J. (1978). Families and the idea of family policy. In S. B. Kamerman \& A. J. Kahn (Eds.), Family policy: Government and families in fourteen countries (pp. 1-16). New York, NY: Columbia University Press.

Kaufmann, F.-X. (2002). Politics and policies towards the family in Europe: A framework and an inquiry into their differences and convergences. In F.-X. Kaufmann, A. Kuijsten, H.-J. Schulze, \& K. P. Strohmeier (Eds.), Family life and family policies in Europe: Problems and issues in comparative perspective. Oxford: Clarendon Press.

Knijn, T., \& Kremer, M. (1997). Gender and the caring dimension of welfare states: Toward inclusive citizenship. Social Politics: International Studies in Gender, State \& Society, 4(3), 328-361.

Korpi, W. (2000). Faces of inequality: Gender, class, and patterns of inequalities in different types of welfare states. Social Politics: International Studies in Gender, State \& Society, 7, 127-191.

Korpi, W., Ferrarini, T., \& Englund, S. (2013). Women's opportunities under different family policy constellations: Gender, class, and inequality tradeoffs in western countries re-examined. Social Politics: International Studies in Gender, State \& Society, 20, 1-40.

Kröger, T. (2011). Defamilisation, dedomestication and care policy: Comparing childcare service provisions of welfare states. International Journal of Sociology and Social Policy, 31, 424-440.

Kurowska, A. (2018). (De)familialization and (de)genderization-competing or complementary perspectives in comparative policy analysis? Social Policy \& Administration, 52(1), 29-49.

Land, H. (1980). The family wage. Feminist Review, 6, 55-77.

Langan, M., \& Ostner, I. (1991). Geschlechterpolitik im Wohlfahrtsstaat: Aspekte im internationalen Vergleich. Krit. Justiz, 24, 302-317.

Leitner, S. (2003). Varieties of familialism: The caring function of the family in comparative perspective. European Societies, 5, 353-375.

Leitner, S., \& Lessenich, S. (2007). (In-)dependence as dependent variable: Conceptualizing and measuring de-familization. In J. Clasen \& N. Siegel (Eds.), Investigating welfare state change: The dependent variable problem in comparative analysis. Cheltenham, UK: Edward Elgar.

Lewis, J. (1992). Gender and the development of welfare regimes. Journal of European Social Policy, 2, 159-173. 
Lewis, J. (1997). Gender and welfare regimes: Further thoughts. Social Politics: International Studies in Gender, State \& Society, 4, 160-177.

Lewis, J. (2001). The decline of the male breadwinner model: Implications for work and care. Social Politics: International Studies in Gender, State \& Society, 8, 152169.

Lewis, J. (2006). Children, changing families and welfare states. Cheltenham, UK: Edward Elgar.

Lewis, J. (2009). Work-family balance, gender and policy. Cheltenham, UK: Edward Elgar.

Lewis, J., Campbell, M., \& Huerta, C. (2008). Patterns of paid and unpaid work in Western Europe: Gender, commodification, preferences and the implications for policy. Journal of European Social Policy, 18, 21-37.

Lewis, J., \& Giullari, S. (2005). The adult worker model family, gender equality and care: The search for new policy principles and the possibilities and problems of a capabilities approach. Economy and Society, 34, 76-104.

Lewis, J., \& Ostner, I. (1994). Gender and the evolution of European social policies ZeS Arbeitspapiere No. 4. Centre for Social Policy Research, University of Bremen, Bremen.

Lister, R. (1994). She has other duties: Women, citizenship and social security. In S. Baldwin \& J. Falkingham (Eds.), Social security and social change: New challenges to the beveridge model (pp. 31-44). Birmingham: Harvester Wheatsheaf.

Lister, R. (2003). Investing in the citizen-workers of the future: Transformations in citizenship and the state under new labour. Social Policy \& Administration, 37, 427-443.

Lohmann, H. (2009). Konzept und Messung von Defamilisierung in international vergleichender Perspektive. In B. Pfau-Effinger S. S. Magdalenić, \& C. Wolf (Eds.), International Vergleichende Sozialforschung. Wiesbaden: VS Verlag für Sozialwissenschaften.

Lohmann, H., \& Zagel, H. (2016). Family policy in comparative perspective: The concepts and measurement of familization and defamilization. Journal of European Social Policy, 26, 48-65.

Lohmann, H., \& Zagel, H. (2018). Comparing family policies: Approaches, methods and databases. In T. Rostgaard, \& G. B. Eydal (Eds.), Handbook of child and family policy (pp. 48-65). Cheltenham, UK: Edward Elgar.

Mathieu, S. (2016). From the defamilialization to the demotherization of care work. Social Politics: International Studies in Gender, State \& Society, 23, 576-591.

McLaughlin, E., \& Glendinning, C. (1994). Paying for care in Europe: Is there a feminist approach? In L. Hantrais \& S. Mangen (Eds.), Family policy and the welfare of women, cross-national research papers (pp. 52-69). University of Loughborough: Loughborough.

O'Connor, J. S. (1993). Gender, class and citizenship in the comparative analysis of welfare state regimes: Theoretical and methodological issues. British Journal of Sociology, 44, 501-518. 
Orloff, A. (1993). Gender and the social rights of citizenship: The comparative analysis of state policies and gender relations. American Sociological Review, 58, 501-518.

Palme, J., \& Heimer, M. (2019). A taxonomy of child policies: Conceptualizing the missing step in defamilization of social policy. Social Politics: International Studies in Gender, State \& Society. https://doi.org/10.1093/sp/jxz016.

Pascall, G. (1996). Social policy: A new feminist analysis (1st ed.). London \& New York, NY: Routledge.

Pfau-Effinger, B. (1996). Analyse internationaler Differenzen in der Erwerbsbeteiligung von Frauen: Theoretischer Rahmen und empirische Ergebnisse. Kölner Zeitschrift für Soziologie und Sozialpsychologie, 48(3), 462-492.

Pfau-Effinger, B. (2005). Welfare state policies and the development of care arrangements. European Societies, 7, 321-347.

Sainbury, D. (1994). Introduction. In D. Sainsbury (Ed.), Gendering welfare states (pp. 1-7). London: Sage.

Sainsbury, D. (1996). Gender, equality, and welfare states. Cambridge: Cambridge University Press.

Saraceno, C. (1997). Family change, family policies and the restructuring of welfare. In M. Pearson \& P. Hennessy (Eds.), Family, market and community: Equity and Efficiency in Social Policy (pp. 81-100). Paris: OECD Publishing.

Saraceno, C., \& Keck, W. (2010). Can we identify intergenerational policy regimes in Europe? European Societies, 12, 675-696.

Saxonberg, S. (2013). From defamilialization to degenderization: Toward a new welfare typology. Social Policy \& Administration, 47, 26-49.

Skocpol, T., \& Amenta, E. (1986). States and social policies. Annual Review of Sociology, 12, 131-157.

Zagel, H., \& Lohmann, H. (forthcoming). Conceptualising state-market-family relationships in comparative research: A conceptual goodness view on defamilization. Journal of Social Policy

Open Access This chapter is licensed under the terms of the Creative Commons Attribution 4.0 International License (http://creativecommons.org/licenses/by/4.0/), which permits use, sharing, adaptation, distribution and reproduction in any medium or format, as long as you give appropriate credit to the original author(s) and the source, provide a link to the Creative Commons licence and indicate if changes were made.

The images or other third party material in this chapter are included in the chapter's Creative Commons licence, unless indicated otherwise in a credit line to the material. If material is not included in the chapter's Creative Commons licence and your intended use is not permitted by statutory regulation or exceeds the permitted use, you will need to obtain permission directly from the copyright holder.

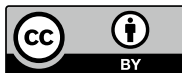

